\title{
Distribution of Plasmodium vivax pvdhfr and pvdhps alleles and their association with sulfadoxine-pyrimethamine treatment outcomes in Indonesia
}

\author{
Puji B. S. Asih" ${ }^{*}$, Sylvia S. Marantina', Rodiah Nababan' ${ }^{1}$, Neil F. Lobo ${ }^{2}$, Ismail E. Rozi ${ }^{1}$, Wajio Sumarto', \\ Rita M. Dewi ${ }^{3}$, Sekar Tuti ${ }^{3}$, Ahmad S. Taufik ${ }^{4}$, Mulyanto $^{5}$, Robert W. Sauerwein ${ }^{6}$ and Din Syafruddin ${ }^{1,7}$
}

\begin{abstract}
Background: Sympatric existence of Plasmodium falciparum and Plasmodium vivax, and the practice of malaria treatment without microscopic confirmation suggest that the accidental treatment of vivax malaria with sulfadoxinepyrimethamine (SP) is common.

Methods: In this study, the frequency distribution of alleles associated with SP resistance were analysed among the $P$. vivax infections from malariometric surveys and its association with SP treatment failure in clinical studies in Indonesia. The $d h f r$ and dhps alleles were detected using PCR-RFLP method.

Results: Analysis of 159 P. vivax isolates from malariometric surveys and 69 samples from in vivo SP efficacy study revealed various the existence of various alleles of the pvdhfr and pfdhps genes including 57L/l, 58R, 61M, and 117N/T. Allele $13 \mathrm{~L}$ of the dhfr gene and $553 \mathrm{G}$ of the dhps gene were not detected in any isolates examined in both studies. In the dhfr gene, tandem repeat type-A was the major tandem repeat observed in any isolates analysed. In the dhps gene, only the $383 \mathrm{G}$ allele was observed. Isolates carrying double, triple and quadruple mutants of $\mathrm{dhfr}$ gene were found in Lampung, Purworejo, Sumba, and Papua. Although this study revealed a wide distribution of dhfr and dhps alleles among the P. vivax isolates across a broad geographic regions in Indonesia, impact on SP efficacy was not observed in Sumba.
\end{abstract}

Conclusion: With proper malaria diagnosis, SP may still be used as a rational anti-malarial drug either as a single prescription or in combination with artemisinin.

Keywords: Drug resistance, Sulfadoxine-pyrimethamine (SP), Molecular markers, Plasmodium vivax, Indonesia

\section{Background}

Sulfadoxine-pyrimethamine (SP), or Fansidar, a combination anti-malarial drug containing the sulfonamide antibiotic, sulfadoxine and the antiprotozoal pyrimethamine, has long been used as an anti-malarial drug throughout the world. Its easy single-dose prescription and relative efficacy has made this combination an

\footnotetext{
*Correspondence: puji@eijkman.go.id

'Eijkman Institute for Molecular Biology, Jalan Diponegoro 69,

Jakarta 10430, Indonesia

Full list of author information is available at the end of the article
}

excellent choice in the treatment of uncomplicated falciparum malaria and intermittent presumptive treatment in pregnancy (IPTp) in Africa with the advent of chloroquine resistance [1]. Nevertheless, the growing parasite resistance to this drug has limited its use in many parts of the world, including Indonesia.

The molecular basis of parasite resistance to SP has been established in Plasmodium falciparum and rodent Plasmodium, and various single nucleotide polymorphisms (SNPs) in dihydropteroate synthase (dhps) and dihydrofolate reductase $(d h f r)$ genes have been linked to the resistance $[2,3]$. The SP combination has never 
been recommended to treat vivax malaria in Indonesia, however, the sympatric existence of $P$. falciparum and Plasmodium vivax and the practice of malaria treatment without microscopic confirmation suggest that accidental treatment of vivax malaria with SP has often taken place. Treatment of patients with SP has inadvertently led to the simultaneous selection of SPresistant $P$. vivax. In Indonesia before 2004, SP was used alone as a second-line anti-malarial drug for falciparum malaria [4]. Although SP has never been recommended for the treatment of patients with $P$. vivax malaria, the selection pressure exerted by the drug is expected to have continued progressively in $P$. falciparum and $P$. vivax [5]. Since 2010, vivax malaria cases in Indonesia are treated with artemisinin-based combination therapy (ACT) [6].

Pyrimethamine inhibits the $d h f r$ enzyme [7] and sulfadoxine targets the dhps enzyme in the folate biosynthetic pathway of the parasite [8]. Point mutations in parasite $d h f r$ and dhps genes confer resistance to SP in $P$. falciparum. High level resistance to pyrimethamine in P. falciparum results from the accumulation of mutations in pfdhfr principally at codons $16,51,59,108$, and $164[9,10]$. These mutations have been shown to alter the pyrimethamine binding sites in $p f d h f r$ and reduce enzyme drug interaction [11]. Twenty non-synonymous mutations have already been described in the $p v d h f r$ gene $[5,12]$. Some of these mutations (at codon 57, 58, 61,117 , and 173) are involved in resistance to pyrimethamine $[13,14]$. Five mutations have already been identified in the pvdhps gene, at codon $382,383,512,553$, and 585 , corresponding to position $436,437,540,581$, and 613 of the homologues gene in the P. falciparum [3, 14, 15]. The $p v d h f r$ and $p v d h p s$ genotypes might be associated with treatment failure in individual vivax malaria patients [16]. Limited data are available about polymorphisms in $p v d h f r$ and $p v d h p s$ genes of malaria parasites from Indonesia. Previous data from Lampung show triple mutation found in this area [17] and a quadruple mutant 49R/57L/58R/61M/117T was found in Papua $[17,18]$.

The extent of genetic polymorphisms associated with resistance to SP was screened among the $P$. vivax isolates in Indonesia towards evaluating the use of SP for the treatment of $P$. vivax malaria and the possible use of SP for IPTp.

\section{Methods}

Plasmodium vivax isolates were obtained from two different studies: (1) malariometric surveys in five malariaendemic areas; and, (2) in vivo SP efficacy study in Southwest Sumba District.

\section{Malariometric survey (sample set 1 )}

Blood blots on filter paper (3 MM; Whatman, Hillsboro, OR, USA) containing approximately $50 \mu \mathrm{L}$ blood equivalent were collected from five selected malaria-endemic areas: Lampung, Purworejo, Mataram, Sumba, and Papua (September 2006-August 2008) (Fig. 1).

\section{In vivo sulfadoxine-pyrimethamine efficacy study (sample set 2)}

The study was conducted in Southwest Sumba District, East Nusa Tenggara Province from September 2009 to February 2010 (Fig. 1). The subjects were recruited from a pool of malaria-infected individuals identified during an active malariometric survey. Subjects were excluded if they met any of the following exclusion criteria: (1) were pregnant; (2) history of allergy to the study drugs or study drugs' derivative; (3) completed treatment with an anti-malarial drug in the preceding 2 weeks; or, (4) medical history of untreated hypertension or chronic heart, kidney or liver disease. Plasmodium vivax-infected subjects did not show any signs of severe malaria. All study subjects were supervised in their treatment with SP tablets $(30 \mathrm{mg}$ sulfadoxine and $1.5 \mathrm{mg}$ pyrimethamine per $\mathrm{kg}$ body weight, according to national treatment guidelines) and followed for 28 days. A study nurse gave medication, observed and recorded all treatments, and repeated the treatment if vomiting occurred within $30 \mathrm{~min}$ of the administered dose. Parasitological responses were classified according to criteria set by WHO [19]. At enrolment, a finger prick was performed to make thick and thin blood smears, blots on filter paper (Whatman, Schleicher and Schuell, Whatman International Ltd, Maidstone, UK) for further parasite genotyping, and haemoglobin measurement using hemocue (HemocueTM Hb201+, Angelholm, Sweden). Blood smears and filter-paper blood samples were also collected from finger pricks on days $1,2,3,7,14,21$, and 28 . Smears were read by expert microscopists and confirmed by polymerase chain reaction (PCR). Adverse effects observed during the study were recorded by the study nurse and/or physician. Primaquine therapy against relapse was not provided until discontinuation from the study, i.e., day of recurrence or day 28. This study has been approved by the Eijkman Institute Research Ethics Committee for the use of human subjects.

\section{Malaria microscopy}

All blood slide thick and thin blood smears were stained with Giemsa, and subsequently examined by light microscopy. Parasite density was determined by counting the number of parasites per leukocytes in 100-high-power 


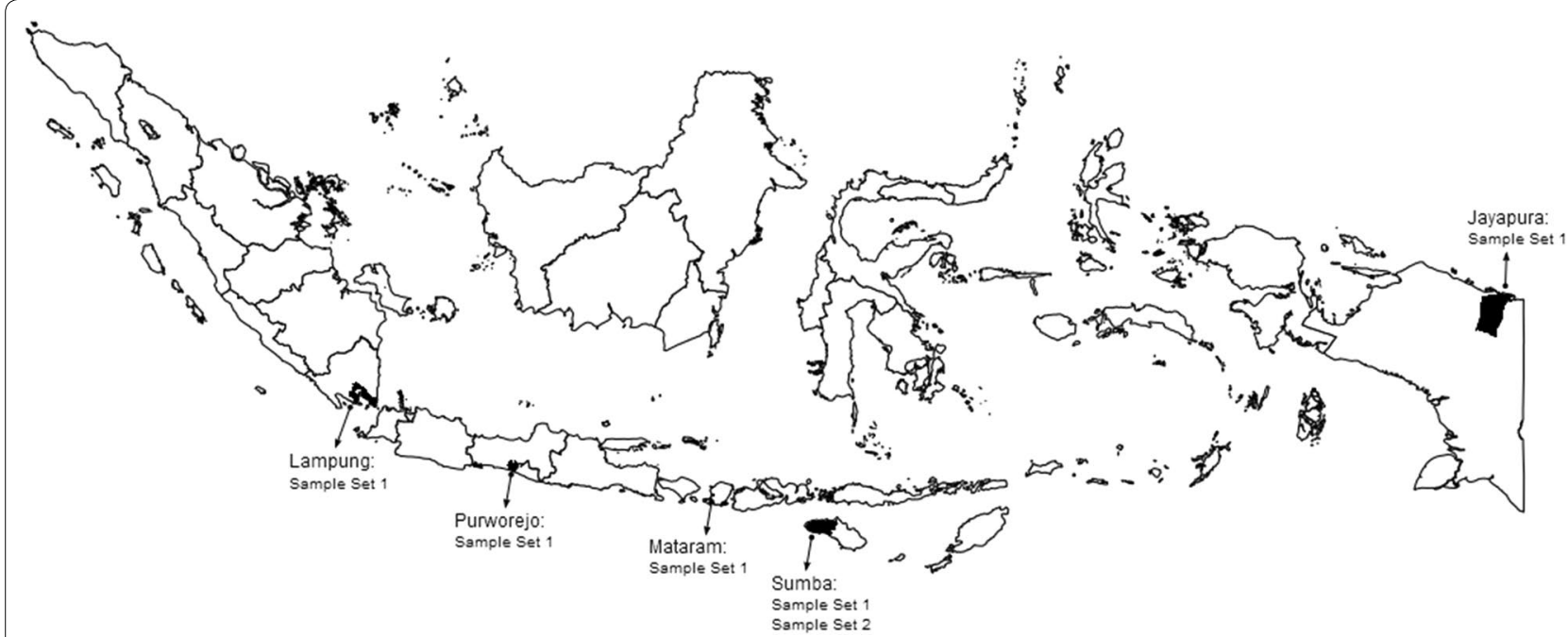

Fig. 1 The origin of Plasmodium vivax isolate for sample sets 1 and 2. (1) Lampung, south of Sumatera; (2) Purworejo, Central Java; (3) Mataram, West Nusa Tenggara; (4) Sumba (East Nusa Tenggara); and, (5) Jayapura, Papua

microscopic fields in a Giemsa-stained thick film, assuming an average of 20 leukocytes/microscopic field and 8000 leukocytes/ $\mu$ l blood. The total number of parasites/ $\mu \mathrm{l}$ was multiplied by 40 [20].

\section{Genomic DNA preparation}

DNA from all samples (including sample set 2, on day of enrolment and day of recurrence) were extracted from the blood samples using Chelex-100 ion exchanger (Biorad Laboratories, Hercules, CA, USA) [21]. The filter papers were placed in a microtube, $100 \mu$ distilled water and $50 \mu \mathrm{l} 20 \%$ Chelex-100 in distilled water were added. DNA was extracted by boiling at $100{ }^{\circ} \mathrm{C}$ for $10 \mathrm{~min}$. The extracted DNA was either used immediately for PCR assays or stored at $-20{ }^{\circ} \mathrm{C}$ for later analysis.

\section{Confirmation of Plasmodium vivax species}

A nested PCR diagnosis was performed using the $18 \mathrm{~S}$ rRNA gene diagnostic [22] in both sets of sample isolates.

\section{Amplification and analysis of pvdhfr and pvdhps gene mutation}

The nested PCR amplification strategies for $p v d h f r$ and pvdhps genes were designed using previously published results $[5,23]$. Two fragments were obtained by nestedPCR: one being used for the analysis of F57L/I, S58R, $\mathrm{T} 61 \mathrm{M}$, and $\mathrm{S} 117 \mathrm{~N} / \mathrm{T}$ and the other for the examination of I13L, F57L/I, S58R, and T61M alleles. Both pvdhfr gene tandem repeat variants $[7,24]$ were observed and designated as type A (three tandem repeat GGDN TS GGDN TH GGDN) and type B (two tandem repeat GGDN TS GGDN and deletion at 98-103 residue). The amplified fragment of the pvdhps gene corresponds to GenBank acc no. AY186730 and detects mutations A383G and A553G [23].

\section{Results}

All Plasmodium infection isolates were confirmed as $P$. vivax by PCR diagnosis, performed using $18 \mathrm{~S}$ rRNA gene primer. The analysis of these $P$. vivax isolates indicated that several isolates carried mutant alleles of the $P v d h f r$, such as $57 \mathrm{~L} / \mathrm{I}, 58 \mathrm{R}, 61 \mathrm{M}$, and $117 \mathrm{~N} / \mathrm{T}$ and allele $383 \mathrm{G}$ of the Pvdhps genes.

\section{Malariometric survey (sample set 1) \\ Mutant alleles of the dhfr gene}

Of the 159 isolates screened for $p v d h f r$ mutations from five different malaria endemic areas, 131 were found to carry at least one of the pvdhfr mutant alleles and 28 isolates $(21 \%)$ carried no mutant allele. The allele with the highest prevalence was $117 \mathrm{~N}$ (27\%), followed by $117 \mathrm{~T}(18 \%)$. Isolates carried the double mutant $(58 \mathrm{R} / 117 \mathrm{~N})$ were found in three sites: Papua, Lampung and Purworejo, with the highest prevalence observed in Lampung (23\%). Plasmodium vivax isolates with a double mutant $d h f r$ allele were not found in Sumba and Mataram. The triple $(58 \mathrm{R} / 61 \mathrm{M} / 117 \mathrm{~T})$ and quadruple (57L/58R/61M/117T) mutant alleles were found with prevalences of 3 and $18 \%$, respectively (Table 1 ). Mutations at codon I13L were not detected in any of the samples analysed. Three types of allelic combination of the $d h f r$ gene were identified from Papua, while two types were identified from Lampung and Purworejo. One type of allelic combination was found from Sumba. Tandem repeat type A was the major tandem repeat observed among the $P$. vivax isolates in all sites. The frequency 
Table 1 Prevalence of allelic combinations and repetitive motifs in dhfr gene among Plasmodium vivax isolates in Indonesia

\begin{tabular}{|c|c|c|c|c|c|}
\hline \multirow[t]{2}{*}{ Type } & \multicolumn{5}{|c|}{ Prevalence in malaria-endemic areas (\%) } \\
\hline & Papua & Lampung & Purworejo & Sumba & Mataram \\
\hline \multicolumn{6}{|l|}{ Allelic combination } \\
\hline $58 \mathrm{R} / 117 \mathrm{~N}$ & $11.8(4 / 34)$ & $96.3(26 / 27)$ & $60(6 / 10)$ & $0(0 / 60)$ & $0(0 / 28)$ \\
\hline $58 \mathrm{R} / 61 \mathrm{M} / 117 \mathrm{~N}$ & $2.9(1 / 34)$ & $11.1(3 / 27)$ & $0(0 / 10)$ & $0(0 / 60)$ & $0(0 / 28)$ \\
\hline 57L/58R/61M/117T & $61.8(21 / 34)$ & $0(0 / 27)$ & $10(1 / 10)$ & $3.3(2.60)$ & $0(0 / 28)$ \\
\hline \multicolumn{6}{|c|}{ Repetitive motifs GGDN (units) } \\
\hline Type $A=$ three units & $100(34 / 34)$ & $66.7(18 / 27)$ & $100(10 / 10)$ & $85.7(24 / 28)$ & $92.9(26 / 28)$ \\
\hline Type $B=$ two units & $0(0 / 34)$ & $33.3(9 / 27)$ & $0(0 / 10)$ & $14.3(4 / 28)$ & $7.1(2 / 28)$ \\
\hline
\end{tabular}

distribution of tandem repeat A ranged from 66.7 to $100 \%$ (Table 1).

\section{Mutant alleles of the dhps gene}

Analysis of the 159 P. vivax isolates revealed only one mutant allele of the dhps gene, 383G, in three sites with prevalence of 33, 15 and $9 \%$ in Papua, Purworejo and Sumba, respectively. Mutant allele 553G was not observed in any of the isolates examined.

\section{In vivo sulfadoxine-pyrimethamine efficacy study (sample} set 2)

Of the 500 subjects screened, 69 subjects met the inclusion criteria and were recruited for this study. Characteristic of the subject is shown in Table 2. Sixty-three (94\%) subjects were successfully cleared their parasitaemia before day 7 and completely recovered up to day 28 (Table 3$)$. One subject (1.5\%) was found to carry parasites at day 14. Three subjects were lost to follow-up and two subjects dropped out (Table 3 ). No severe side effects were noted in any of the 69 subjects enrolled.

Table 2 Characteristics of the subjects at enrolment in the $\mathbf{2 8}$ days in vivo sulfadoxine-pyrimethamine test in Sumba

Number of subjects

Median (range) age (year)

Median (range) haemoglobin level (day 0) (g/dl)

69

$13.2(2-60)$

Geometric mean asexual parasitaemia/ $\mu$ l blood

$13.2(9.4-16.2)$

$893(40-19,600)$

Table 3 Plasmodium vivax phenotyping sulfadoxinepyrimethamine in Sumba

\begin{tabular}{llllll}
\hline Total subject & ETF & LTF & ACPR & LTFU & Drop-out \\
\hline 69 & 0 & $1^{\text {a }}$ & 63 & 3 & 2 \\
\hline
\end{tabular}

ETF early treatment failure, LTF late treatment failure, $A C P R$ adequate clinical parasitological response, LTFU lost to follow-up

a Day 14

\section{Mutant alleles of the pvdhfr gene}

Various types of allelic combination of $d h f r$ gene mutants were identified from in vivo SP efficacy study in Sumba (Table 4). Analysis of the pvdhfr gene of the 69 subjects at day 0 and one subject at day 14 revealed the existence of four mutant alleles: 57L/I, 58R, 61M, and $117 \mathrm{~N} / \mathrm{T}$, either as a single mutation or in combination with the

Table 4 Allelic combination in dhfr and dhps genes among the sulfadoxine-pyrimethamine efficacy samples

\begin{tabular}{|c|c|c|c|c|c|}
\hline \multicolumn{5}{|c|}{ Type of allelic combination } & \multirow{2}{*}{$\begin{array}{l}\text { Total } \\
\text { isolate }\end{array}$} \\
\hline F57I/L & S58R & $\mathrm{T61M}$ & $\mathrm{S} 117 \mathrm{~T} / \mathrm{N}$ & A383G & \\
\hline $\mathrm{F}$ & $\mathrm{R}$ & M & $S$ & A & $13^{\mathrm{a}}$ \\
\hline $\mathrm{F}$ & $\mathrm{R}$ & M & $\mathrm{T}$ & G & 11 \\
\hline $\mathrm{L}$ & $\mathrm{R}$ & M & $S$ & G & 8 \\
\hline $\mathrm{F}$ & $S$ & M & $S$ & G & 6 \\
\hline $\mathrm{L}$ & $\mathrm{R}$ & M & $\mathrm{T}$ & A & 5 \\
\hline $\mathrm{F}$ & $\mathrm{R}$ & M & $\mathrm{T}$ & A & 3 \\
\hline $\mathrm{F}$ & $\mathrm{R}$ & M & $\mathrm{N}$ & A & 3 \\
\hline $\mathrm{F}$ & $\mathrm{R}$ & $M$ & $S$ & $\mathrm{G}$ & 3 \\
\hline $\mathrm{F}$ & $\mathrm{S}$ & $M$ & $\mathrm{~T}$ & $A$ & 3 \\
\hline $\mathrm{L}$ & $\mathrm{R}$ & $M$ & $S$ & $A$ & 2 \\
\hline $\mathrm{F}$ & $S$ & $\mathrm{~T}$ & $\mathrm{~N}$ & $\mathrm{G}$ & 2 \\
\hline $\mathrm{F}$ & $S$ & $M$ & $S$ & $A$ & 1 \\
\hline $\mathrm{L}$ & $S$ & $M$ & $\mathrm{~T}$ & $\mathrm{G}$ & 1 \\
\hline $\mathrm{L}$ & $S$ & $\mathrm{~T}$ & $S$ & $A$ & 1 \\
\hline $\mathrm{F}$ & $\mathrm{R}$ & $\mathrm{T}$ & $\mathrm{N}$ & $A$ & 1 \\
\hline $\mathrm{L}$ & $\mathrm{R}$ & $\mathrm{T}$ & $\mathrm{N}$ & $\mathrm{G}$ & 1 \\
\hline $\mathrm{F}$ & $\mathrm{S}$ & $\mathrm{T}$ & $\mathrm{T}$ & $A$ & 1 \\
\hline $\mathrm{L}$ & $S$ & $M$ & $\mathrm{~T}$ & $A$ & 1 \\
\hline $\mathrm{F}$ & $\mathrm{S}$ & $M$ & $\mathrm{~T}$ & $\mathrm{G}$ & 1 \\
\hline $\mathrm{L}$ & $\mathrm{R}$ & $M$ & $\mathrm{~T}$ & $\mathrm{G}$ & 1 \\
\hline $\mathrm{F}$ & $S$ & $M$ & $\mathrm{~N}$ & $A$ & 1 \\
\hline $\mathrm{F}$ & $R$ & $M$ & $\mathrm{~N}$ & $\mathrm{G}$ & 1 \\
\hline
\end{tabular}

Total isolates $=70 ; 69$ isolates D0; 1 isolate DR

${ }^{\text {a }}$ For recurrence isolate, genotype day $0=$ day 14 
other alleles. A single mutation at codon 57L, 61M, $117 \mathrm{~N}$, and $117 \mathrm{~T}$ was found with frequencies of 1.4, 8.6, 2.8 , and $1.4 \%$, respectively. Allele I13L was not detected in any of the isolates examined. Double mutants with four types of allelic combination (58R/61M, 58R/117N, $61 \mathrm{M} / 117 \mathrm{~T}, 61 \mathrm{M} / 117 \mathrm{~N})$ were found in 24 isolates $(34.3 \%)$ including the recurrent isolate at day 14 . Triple mutants with five types of allelic combination (58R/61M/117T, $57 \mathrm{~L} / 58 \mathrm{R} / 61 \mathrm{M}, 58 \mathrm{R} / 61 \mathrm{M} / 117 \mathrm{~N}, \quad 57 \mathrm{~L} / 61 \mathrm{M} / 117 \mathrm{~T}$, and $57 \mathrm{~L} / 58 \mathrm{R} / 117 \mathrm{~N}$ ) were observed in 27 isolates (38.6\%). The quadruple mutant, $57 \mathrm{~L} / 58 \mathrm{R} / 61 \mathrm{M} / 117 \mathrm{~T}$, was found in one isolate $(1.4 \%)$. Tandem repeat type $\mathrm{A}$ was also the major tandem repeat observed in isolates analysed, including the recurrent isolate at day 14.

\section{Mutant alleles of the pvdhps gene}

Analysis of the pvdhps gene of the 70 subjects revealed only one mutant allele, $383 \mathrm{G}$ in 35 subjects $(50 \%)$. The recurrent isolates at day 14 carried no mutant alleles of the dhps gene.

\section{Discussion}

Analysis of the pvdhfr and pvdhps genes in P. vivax isolates from five different malaria-endemic areas in Indonesia revealed a wide distribution of the mutant alleles associated with resistance to SP. The mutant alleles of the $d h f r$ gene were found either as single polymorphisms or in combination with other polymorphisms. With the dhps gene, 383G was the only mutant allele observed. Previous reports found similar polymorphisms in P. vivax isolates from Lampung and Papua [17, 18]. The findings indicate that the SP drug pressure to $P$. vivax may have taken place at all sites and that mistreatment of $P$. vivax malaria infections may be widespread. Until 2010, the recommended drug for vivax malaria was the combination of chloroquine with primaquine but due to the spread of chloroquine resistance to $P$. falciparum and $P$. vivax, ACT was introduced [24].

Three types of allelic combination of $p v d h f r$ gene were observed among the $P$. vivax isolates from the five malariaendemic areas investigated. These included double, triple and quadruple mutants. Overall, when looking at the allelic combinations, the frequency of double mutants was $22.6 \%$ (36 isolates), triple mutants was $2.5 \%$ (four isolates) and quadruple mutants was $15.1 \%$ (24 isolates). Plasmodium vivax isolates from Papua were dominated by quadruple mutants $(61.8 \%)$. Nevertheless, the in vivo study in Sumba to determine the molecular basis of SP treatment failure in $P$. vivax indicated that all $P$. vivax isolates that carried the aforementioned allelic combination were still susceptible to SP, except in one recurrent isolate at day 14 with the double dhfr mutants, 58R/61M.
Mutations in pvdhfr and dhps genes, including 58R and $117 \mathrm{~N}$, have been implicated in pyrimethamine and sulfadoxine resistance, respectively [25]. In P. falciparum, the existence of quintuple mutations, three in $d h f r$ gene (S118N, C59R and N51C) and two in dhps gene (A437G and $\mathrm{K} 540 \mathrm{E}$ ), have been associated with SP treatment failure [26-28]. The corresponding mutations in P. vivax are $117 \mathrm{~N}, 58 \mathrm{R}$ and $49 \mathrm{R}$ in $d h f r$ gene and $383 \mathrm{G}$ and $553 \mathrm{G}$ in dhps gene. Although $d h f r$ mutations have been widespread among the $P$. vivax isolates, mutations at the dhps gene are still rare. The $383 \mathrm{G}$ allele was found in various frequency among the isolates examined and the highest frequency was observed in Purworejo.

Two and three GGDN repeat units were detected in wild and mutant types $d h f r$ in all allelic combination. This result corroborates the previous results where an insertion/deletion event within the short repetitive region did not appear to be clearly associated with antifolate resistance. However, repetitive sequences that produce length polymorphism may not affect pyrimethamine sensitivity [24].

The wide distribution of $d h f r$ and $d h p s$ gene polymorphisms among the $P$. vivax field isolates seems to have little implication on the efficacy of SP combination treatment. This was demonstrated in the in vivo study in west Sumba District, where the efficacy of SP was still very high (94\%). This is the first report from Indonesia that demonstrates that $P$. vivax is highly sensitive to SP. The results of this study however require further observation in areas where SP was reported to be resistant to $P$. falciparum, such as Papua [18]. Unfortunately, with current policy that adopted ACT as first-line therapy for both $P$. vivax and $P$. falciparum, it will be difficult to justify a study to monitor the efficacy of SP anymore. Nevertheless, SP may be considered as a rational option for the treatment of vivax malaria either given alone or in combination with artemisinin. Previous studies in Pakistan and Afghanistan also found high efficacy of SP in the treatment of vivax malaria [29].

Most subjects carried triple and quadruple mutations in the $d h f r$ gene in addition to the mutaion in dhps 383G, but still were sensitive to the SP. The only subject who showed late treatment failure carried the double mutations in $d h f r$ without any $d h p s$ gene mutation. Here, it is not clear as to whether this parasite originated from new infection or was a recurrence from the current infection, keeping in mind that previous results indicate that hypnozoites may have a different genotype than that of the initial infection [30, 31]. Nonetheless, as SP has a long half-life, any parasite that was detected during the monitored 42-day treatment should be relatively resistant to SP. Previous results from Thailand also show inconclusive 
results upon the association between the dhfr and dhps mutations to the SP treatment outcome. Although it is clear that the isolates that carry multiple mutations in $d h f r$ and $d h p s$ are associated with high grade SP resistance, many of the isolates still respond adequately to the SP [23]. In this regard, it is important to note that in Indonesia, the proportion of $P$. vivax isolates that carry double mutant dhps is still very rare and in fact was only reported in the isolates collected from northeastern Papua. Papua, with the highest amount of malaria and consequent highest selection pressure from mistreatment of vivax infections with SP, may explain this high number of multiple resistant alleles. These results may explain why the $P$. vivax isolates in Sumba are still susceptible to SP and this also may be true of the isolates from Lampung, Purworejo, Mataram and, to a lesser extent, in Papua.

The development and spread of drug-resistant parasite strains is a major obstacle to the malaria control and elimination programme. As the molecular basis of the parasite resistance to antifolates and sulfa drugs has been well established in Plasmodium spp., analysis on the frequency distribution of $d h f r$ and dhps mutant alleles would provide a better perspective on the use of SP in a particular area. In this regard, it is important to notice an increasing prevalence of $P$. vivax isolates carrying the triple mutants of $d h f r$ gene in all sites and particularly the quadruple mutants of $d h f r$ gene in northeastern Papua regions.

\section{Conclusions}

This study revealed a wide distribution of $d h f r$ and $d h p s$ mutant alleles among $P$. vivax isolates across broad geographic regions of Indonesia, but an impact on the SP efficacy was not observed at this point. Therefore, with proper malaria diagnosis, SP may still be used as a rational anti-malarial drug, either as a single prescription or in combination with artemisinin.

\begin{abstract}
Authors' contributions
PBSA and DS conceived the study, and participated in its design and drafted the first manuscript. PBSA, SSM, RN, WS, RMD, S, AST, and M assisted in field work. IER was engaged in data collection, cleaning, analysis and contributed to data interpretation. PBSA, SSM and RN performed the PCR with input from PBSA. PBSA and DS supervised the laboratory procedures and PCR quality control. DS, NFL and RWS oversaw the study design and provided input to data analysis, interpretation and helped check the draft manuscript. All authors contributed to submitted version of the manuscript. All authors read and approved the final manuscript.
\end{abstract}

\footnotetext{
Author details

${ }^{1}$ Eijkman Institute for Molecular Biology, Jalan Diponegoro 69, Jakarta 10430, Indonesia. ${ }^{2}$ Eck Institute for Global Health, University of Notre Dame, Notre Dame, IN, USA. ${ }^{3}$ Department of Biomedicine and Pharmacology, National Institute for Health Research and Development, Jakarta, Indonesia. ${ }^{4}$ Immunobiology Laboratory, School of Medicine, University of Mataram, Mataram, Indonesia. ${ }^{5}$ West Nusa Tenggara Hepatitis Laboratory, Mataram, Indonesia. ${ }^{6}$ Department of Medical Microbiology, Radboud University Nijmegen Medical
}

Centre, Nijmegen, The Netherlands. ${ }^{7}$ Department of Parasitology, Faculty of Medicine, Hasanuddin University, Makasar, Indonesia.

\section{Acknowledgements}

Samples collection in Lampung, Purworejo and Mataram were supported by Research Grant from The Ministry of Research and Technology, Republic of Indonesia, through Eijkman Institute for Molecular Biology, Jakarta. Sample collection in Sumba, Papua and molecular assays for all samples collected were supported by a Grant-InAid from The Netherlands Foundation for the Advancement of Tropical Research, The Netherlands Foundation for Health Research and Development through PRIOR Programme Project-11. The authors are grateful to individuals who participated in this study. We thank the Eijkman Institute for Molecular Biology, Jakarta, professional staff at Department of Health Jakarta, US NAMRU-2 Jakarta, Provincial Health Department, District Health Department and Puskesmas at study sites in Lampung, Purworejo, Mataram, Sumba and Papua, for the support, encouragement and help with sample collection.

\section{Compliance with ethical guidelines}

\section{Competing interests}

The authors declare that they have no competing interests.

Received: 29 June 2015 Accepted: 12 September 2015

Published online: 22 September 2015

\section{References}

1. WHO. Strategic framework for malaria prevention and control during pregnancy in the Africa Region. World Health Organization, Regional Office for Africa, Brazzaville, AFR/MAL/04/01. 2004.

2. Foote SJ, Galatis D, Cowman AF. Amino acids in the dihydrofolate reductase-thymidylate synthase gene of Plasmodium falciparum involved in cycloguanil resistance differ from those involved in pyrimethamine resistance. Proc Natl Acad Sci USA. 1990;87:3014-7.

3. Triglia T, Cowman AF. Primary structure and expression of the dihydropteroate synthetase gene of Plasmodium falciparum. Proc Natl Acad Sci USA. 1994;91:7149-53.

4. Ministry of Health, Republic of Indonesia: Bulletin Kesehatan. Buku saku pedoman pengobatan malaria di Indonesia. 2004.

5. Imwong M, Pukrittayakamee S, Rénia L, Letourneur F, Charlieu JP, Leartsakulpanich $U$, et al. Novel point mutations in the dihydrofolate reductase gene of Plasmodium vivax: evidence for sequential selection by drug pressure. Antimicrob Agents Chemother. 2003;47:1514-21.

6. Ministry of Health, Republic of Indonesia: Bulletin Kesehatan. Buku saku pedoman pengobatan malaria di Indonesia. 2010.

7. De Pécoulas PE, Tahar R, Ouatas T, Mazabraud A. Sequence variations in the Plasmodium vivax dihydrofolate reductase-thymidylate synthase gene and their relationship with pyrimethamine resistance. Mol Biochem Parasitol. 1998;92:265-73.

8. Triglia T, Menting JG, Wilson C, Cowman AF. Mutations in dihydropteroate synthase are responsible for sulfone and sulfonamide resistance in Plasmodium falciparum. Proc Natl Acad Sci USA. 1997;94:13944-9.

9. Auliff A, Wilson DW, Russell B, Gao Q, Chen N, Anh LN, et al. Amino acid mutations in Plasmodium vivax dhfr and dhps from several geographical regions and susceptibility to antifolate drug. Am J Trop Med Hyg. 2006;75:617-21.

10. Sibley $\mathrm{CH}$, Hyde JE, Sims PF, Plowe CV, Kublin JG, Mberu EK, et al. Pyrimethamine-sulfadoxine resistance in Plasmodium falciparum: what next? Trends Parasitol. 2001;17:582-8.

11. Yuvaniyama J, Chitnumsub P, Kamchonwongpaisan S, Vanichtanankul J, Sirawaraporn W, Taylor P, et al. Insights into antifolate resistance from malarial DHFR-TS structures. Nat Struct Biol. 2003;10:357-65.

12. Hawkins VN, Auliff A, Prajapati SK, Rungsihirunrat K, Hapuarachchi HC, Maestre A, et al. Multiple origins of resistance-conferring mutations in Plasmodium vivax dihydrofolate reductase. Malar J. 2008;7:72.

13. Hawkins VN, Joshi H, Rungsihirunrat K, Na-Bangchang K, Sibley CH. Antifolates can have a role in the treatment of Plasmodium vivax. Trends Parasitol. 2007;23:213-22. 
14. Imwong M, Sudimack D, Pukrittayakamee S, Osorio L, Carlton JM, Day NPJ, et al. Microsatellite variation, repeat array length, and population history of Plasmodium vivax. Mol Biol Evol. 2006;23:1016-8.

15. Hawkins VN, Suzuki SM, Rungsihirunrat K, Hapuarachchi HC, Maestre A, $\mathrm{Na}$-Bangchang $\mathrm{K}$, et al. Assessment of the origins and spread of putative resistance-conferring mutations in Plasmodium vivax dihydropteroate synthase. Am J Trop Med Hyg. 2009;81:348-55.

16. Kaura S, Prajapatib SK, Kalyanaramana K, Mohmmeda A, Joshib H, Chauhan VS. Plasmodium vivax dihydrofolate reductase point mutations from the Indian subcontinent. Acta Trop. 2006;97:174-80.

17. Hastings MD, Porter KM, Maguire JD, Susanti I, Kania W, Bangs MJ, et al Dihydrofolate reductase mutations in Plasmodium vivax from Indonesia and therapeutic response to sulfadoxine plus pyrimethamine. J Infect Dis. 2004; 189:744-50

18. Tjitra E, Baker J, Suprianto S, Cheng Q, Anstey NM. Therapeutic efficacies of artesunate-sulfadoxine-pyrimethamine and chloroquine-sulfadoxine-pyrimethamine in vivax malaria pilot studies: relationship to Plasmodium vivax dhfr mutations. Antimicrob Agents Chemother 2002;46:3947-53.

19. WHO. Monitoring antimalarial drug resistance. Report of a WHO consultation. World Health Organization, Geneva, Switzerland. 2002.

20. Gilles HM. Diagnostic method in malaria. In: Gilles HM, Warrel DA, editors. Bruce-Chwatt's essential malariology. New York: Oxford University Press; 1993. p. 79-95.

21. Wooden J, Kyes S, Sibley CH. PCR and strain identification in Plasmodium falciparum. Parasitol Today. 1993;9:303-5

22. Singh B, Bobogare A, Cox-Singh J, Snounou G, Abdullah MS, Rahman HA. A genus- and species-specific nested polymerase chain reaction malaria detection assay for epidemiologic studies. Am J Trop Med Hyg. 1999;60:687-92

23. Imwong M, Pukrittayakamee $\mathrm{S}$, Cheng Q, Moore C, Looareesuwan $\mathrm{S}$, Snounou G, et al. Limited polymorphism in the dihydropteroate synthetase gene (dhps) of Plasmodium vivax isolates from Thailand. Antimicrob Agents Chemother. 2005;49:4393-5.
24. Asih PBS, Syafruddin D, Leake J, Sorontou Y, Sadikin M, Sauerwein RW, et al. Phenotyping clinical resistance to chloroquine in Plasmodium vivax in Northeastern Papua, Indonesia. Int J Parasitol Drugs Drug Resist. 2011;1:28-32.

25. Rungsihirunrat K, Harnyuttanakorn P, Siripoon N, Seugorn A, Pumpiboon T, Thaithong S. Sequence variations of the Plasmodium vivax dihydrofolate reductase gene from Thai isolates. J Trop Med Parasitol. 2003;26:1-8.

26. Rungsihirunrat K, Sibley CH, Mungthin M, Na-Bangchang K. Geographical distribution of amino acid mutations in Plasmodium vivax DHFR and DHPS from malaria endemic areas of Thailand. Am J Trop Med Hyg. 2008;78:462-7.

27. Basco LK, Tahar R, Ringwald P. Molecular basis of in vivo resistance to sulfadoxine-pyrimethamine in African adult patients infected with Plasmodium falciparum malaria parasites. Antimicrob Agents Chemother. 1998;42:1811-4

28. Jelinek T, Kilian AH, Kabagambe G, von Sonnenburg F. Plasmodium falciparum resistance to sulfadoxine/pyrimethamine in Uganda: correlation with polymorphisms in the dihydrofolate reductase and dihydropteroate synthetase genes. Am J Trop Med Hyg. 1999;61:463-6.

29. Leslie T, Mayan MI, Hasan MA, Safi MH, Klinkenberg E, Whitty CJM, et al. Sulfadoxine-pyrimethamine, chlorproguanil-dapsone, or chloroquine for the treatment of Plasmodium vivax malaria in Afghanistan and Pakistan. JAMA. 2007;297:2201-9.

30. Chen N, Auliff A, Rieckmann K, Gatton M, Cheng Q. Relapses of Plasmodium vivax infection result from clonal hypnozoites activated at predetermined interval. J Infect Dis. 2007;195:934-41.

31. Imwong M, Snounou G, Pukrittayakamee S, Tanomsing N, Kim JR, Nandy $A$, et al. Relapses of Plasmodium vivax infection usually result from activation of heterologous hypnozoites. J Infect Dis. 2007;195:927-33.

\section{Submit your next manuscript to BioMed Central and take full advantage of:}

- Convenient online submission

- Thorough peer review

- No space constraints or color figure charges

- Immediate publication on acceptance

- Inclusion in PubMed, CAS, Scopus and Google Scholar

- Research which is freely available for redistribution

Submit your manuscript at 